\section{Analytics of swelling potential on highly expansive (plastic) clayey soils behavior for sustainable admixture stabilization}

\author{
KenNedy C. ONYELOWE - Department of Civil Engineering, \\ Michael Okpara University of Agriculture, Nigeria • konyelowe@mouau.edu.ng \\ Michael E. ONYIA - Department of Civil Engineering, \\ Faculty of Engineering, University of Nigeria, Nsukka - michael.onyia@unn.edu.ng \\ Duc BUI VAN - Research Group of Geotechnical Engineering, Construction Materials and Sustainability, \\ Hanoi University of Mining and Geology, Vietnam • buivanduc@humg.edu.vn
}

ALI A. FIROOZI - Department of Civil Engineering, Faculty of Engineering and Technology, University of Botswana, Botswana - firoozia@ub.ac.bw

TALAL AMHADI - Department of Construction and Civil Engineering Ecole de Technologie Superieure (ETS), University of Quebec, Canada - talal.amhadi.1@ens.etsmtl.ca Érkezett: 2020. 04. 25. - Received: 25. 04. 2021. - https://doi.org/10.14382/epitoanyag-jsbcm.2021.13

\section{Abstract}

The swelling potential analytics and the ion exchange reaction of highly expansive soils in a soil stabilization process have been reviewed. The importance of these factors in deciding suitable construction materials and chemical additives utilized as alternative or supplementary binders in clayey soil stabilization has been discussed also. The outcome of this study has shown that $\mathrm{Al}^{3+}, \mathrm{Si}^{4+}$, and $\mathrm{Ca}^{2+}$ are the most suitable exchangeable cations with $\mathrm{OH}$ - as the suitable exchangeable anion leading to the formation of $\mathrm{C}-\mathrm{A}-\mathrm{S}-\mathrm{H}$, which is the compound responsible for strengthening. The swelling potential analytics also proposed the expression $w_{\text {sT }}=0.00216$ $\times\left(\sum_{i=1}^{i=n} I_{P_{i}}^{2.44}\right)\left(\sum_{i=D_{1}}^{i=D_{n}} D_{i}\right)$ as the total swelling potential with respect to the depth of a foundation material constructed with clayey soil. This study revealed that during the wet season, hydraulically bound foundation materials experience undesirable volume changes with the highest swelling potential expected at the surface within the active (unstable) zone of the foundation. Generally, the treatment of highly expansive soil with very high swelling potential should be concentrated at the surface and reduced along the depth of the foundation matrix. With this proposed guide, the utilization of alternative or supplementary cementing materials as construction materials in the stabilization of clayey soil to improve swelling can be conducted with a more sustainable approach.

Keywords: swelling potential analytics, adsorbed moisture, double diffused layer, pozzolanic reaction

Kulcsszavak: duzzadási potenciál elemzés, nedvesség, kettôs diffúz réteg, pozzolán reakció

\section{Introduction}

Clayey soils have been considered very important construction materials because of the role they play as foundation materials in earthworks, flexible pavements, compacted clay liners, airfields, backfills, etc. local earthen house builders use clayey soils in their constructions in the countryside [1-3]. This has shown plastic properties that enable the soils clog and bond together in the construction of tach and earthen houses in villages and countryside [4]. This is achieved by mixing clayey soils with moisture sufficient enough to make form clogs and flocs holding the mass together to be used in the local engineering earthworks $[5,6]$. This material is manipulated and handled by mixing it with moisture without recourse to the reason behind its clogging behavior. In advanced foundation earthworks, little consideration has been given to the reactions that lead to bonding together of clayey soil particle when mixed with moisture to its optimum content [7]. It is important to note that the behavior of clayey soils when
Kennedy C. ONYELOWE

is a senior lecturer with a PhD in geotechnica engineering. He teaches and conducts research at the MOUAU, \& AE-FUNAI, Nigeria and KIU,

Uganda. His current research is on artificia intelligence in geoenvironmental engineering and construction materials.

Michael E. ONYIA

is a senior lecturer and published researcher in structural engineering and construction materials. He is a former head of department of civil engineering, UNN, Nigeria.

Duc BUI VAN

s the assistant head of faculty of civil engineering, HUMG, Vietnam, conducts research in geoenvironmental engineering and works as a field engineer.

Ali FIROOZ

is a lecturer and published author at the $\mathrm{UOB}$ Botswana and conducts research in geotechnica engineering and construction materials

Talal AMHADI

is a PhD scholar at the University of Quebec Canada and does research in sustainable pavement materials. mixed with moisture is of utmost importance to geotechnical engineering practice [7]. More so, its behavior when mixed with an admixture during clayey soils stabilization procedure is more important to the designer. In transport geotechnics, pavement underlay is built with clayey soil and in most cases, the clayey soils are of highly plastic and expansive consistency $[8,9]$. These properties make the soils very problematic. Again, when the foundation is exposed to seasonal rise and fall of water table, the clayey soil material responds by undergoing swell and shrink cycle which cause the materials to crack $[1,3$, $10,11]$. These cracks may propagate to such undesirable widths that expose the internal structures of the pavement foundation to moisture percolation from runoff $[1,10]$. The behavior of hydraulically bound structures during the wet and dry season deserve a clearer understanding at this stage. The moisture content increases and attains maximum condition at the surface of clayey soil mass during the wet season when water tables rise and moisture reaches the foundation by capillary rise $[12,13]$. For the maximum moisture at the surface, it 
decreases with depth to a value within the unstable zone or the active zone [12]. Beyond this clayey soil zone of activity is the stable or inactive zone. Hydraulically bound structures built within the unstable or active zone prone to swell and shrink cycles due to moisture intake and loss as the case may be are likely to experience undesirable movements according to the seasons and hence suffer collapse [12]. This is the case with most vertical and horizontal structures that experience failures all over the world $[1,12]$. These are caused primarily due to differential movement in both axial and lateral directions. The mineral contents and more especially the dominant minerals and exchangeable ions in the clayey soils are responsible for the microstructural and macrostructural behavior and reactions that lead to the failure of foundations $[12,14]$. Clayey soils are made of minerals, which are fundamentally responsible for the behaviors observed when mixed with moisture or any additive materials during chemical stabilization [14]. There are three major minerals that may dominate clayey soils, which include kaolinite, illite and montmorillonite as presented in Table 1.

\begin{tabular}{lccc}
\multicolumn{1}{c}{ Mineral } & $\begin{array}{c}\text { Liquid limit, } \\
\mathrm{w}_{\mathbf{L}}(\%)\end{array}$ & $\begin{array}{c}\text { Plastic limit, } \\
\mathrm{w}_{\boldsymbol{p}}(\%)\end{array}$ & Activity, A \\
\hline Kaolinite & $35-100$ & $20-40$ & $0.3-0.5$ \\
\hline Illite & $60-120$ & $35-60$ & $0.5-1.2$ \\
\hline Montmorillonite & $100-900$ & $50-100$ & $1.5-7.0$ \\
\hline Halloysite 1 & $50-70$ & $40-60$ & $0.1-0.2$ \\
\hline Halloysite 2 & $40-55$ & $30-45$ & $0.4-0.6$ \\
\hline Attapulgite & $150-250$ & $100-125$ & $0.4-1.3$ \\
\hline Allophane & $200-250$ & $120-150$ & $0.4-1.3$
\end{tabular}

Table 1 Values of liquid limit, plastic limit and activity of some clay minerals [14] 1. táblázat Egyes agyagásványok folyási határértéke, képlékeny határértéke és aktivitása [14]

It is important that in earthworks, clayey soils are handled by impregnating the mass with moisture to its optimum content as molding moisture $[1,8]$. When this happens, the clayey soils respond by the dispersion of the particles and swelling occurs $[2,11]$. During this hydration reaction stage, the minerals in clay are polarized and the dipole ions migrate to either the surface or the edge [12]. The negative ions of the inundated clay minerals are attracted to the surface of the clayey soil and a film of moisture interface is formed, which is called the adsorbed moisture (see Fig. 1) [7]. When this happens, the soil experiences swelling caused by the weakening of the van der Waal's forces holding the particles together $[7,12,14]$. Around each clayey particle as they separate from each other and as they lose their interparticle force is formed a diffused double layer (DDL) $[6,9,12,15,16]$. This keeps the particles apart and the gap increases as there is further hydration of the clayey soil [7]. Conversely, if dehydration takes place by any means, the diffused double layer reduces and the particles tend to come closer again but the crystalline structure of the clayey soil may be lost due to cracks. This is one the properties of highly expansive soils, which are also called black cotton soils [12]. The swelling cracks in most cases widen to a maximum of $20 \mathrm{~mm}$ and moisture travel deep through these cracks into the ground
[12]. The highly expansive soils swell and shrink in a regular cycle and this brings about severe movements in soil mass and structures built atop are affect by these undesirable behaviors. There is recorded recurring cracking and progressive damage of structures built on these problematic soils [12]. In a polarized clayey soil due to hydration, ions like $\mathrm{Al}^{3+}, \mathrm{Si}^{2+}, \mathrm{Ca}^{2+}, \mathrm{Fe}^{2+}, \mathrm{O}^{-}$ and $\mathrm{OH}^{-}$are observed with $\mathrm{Na}^{+}, \mathrm{K}^{+}$and $\mathrm{Mg}^{2+}$ depending on the dominant clay mineral in the studied clayey soil. Further, ion exchange reaction takes between the exchangeable ions.

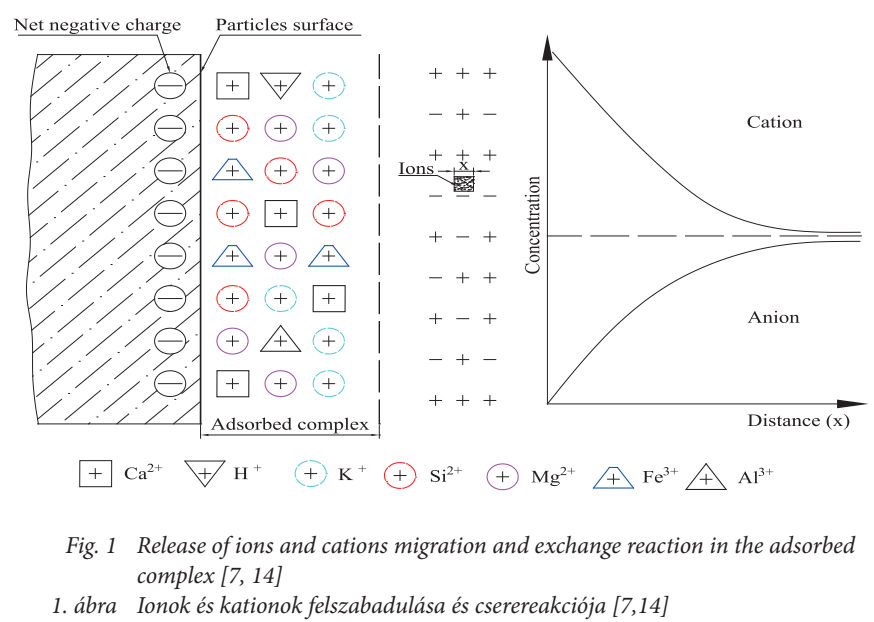

The primary focus of the work is to review the possible exchange reactions that take place during clayey soils stabilization procedure utilizing additives with emphasis on swelling potential analytics [12]. This is important because of the role it plays in the reversal of swell condition of clayey soil, strengthening of highly expansive soils and the achievement of stable and sustainable foundation structures. This aspect of geoenvironmental engineering investigation and more especially soil stabilization and improvement has been neglected by researchers and designers. Without a good understanding and utilizing the knowledge it possesses there will never be any successful stabilization process more so on problematic soils and highly expansive clayey soils would have been useless to earthworks. This review hopes to illuminate this aspect and close the knowledge gap.

\section{Discussion of relevant literatures}

\subsection{Exchangeable ions in soil stabilization}

Clay minerals have atomic structures built of two fundamental crystal sheets, which are the tetrahedral or silica sheet and the octahedral or alumina sheet [8]. It is the metallic ions in the crystals as they are stacked differently with different bonding forces that determine the lattice structure of the clay mineral $[12,14]$. As soon as clayey soils are hydrated as a result of water percolation in hydraulically bound structures or during a stabilization procedure, hydration reaction takes place and exchangeable ions are released with the ionic composition of the pore water. The exchangeable ions available from clay for kaolinite clay mineral (hydrated) with the chemical formula $(\mathrm{OH})_{4} \cdot \mathrm{Al}_{4} \mathrm{Si}_{4} \mathrm{O}_{10} \cdot 4 \mathrm{H}_{2} \mathrm{O}$ are $\mathrm{Al}^{3+}, \mathrm{Si}^{4+}, \mathrm{H}^{+}, \mathrm{OH}^{-}$and $\mathrm{O}^{-}$, for montmorillonite clay mineral with chemical formula $(\mathrm{OH})_{4}$. $\mathrm{Al}_{4} \mathrm{Si}_{\mathrm{g}} \mathrm{O}_{20} \cdot \mathrm{nH}_{2} \mathrm{O}$ are $\mathrm{Al}^{3+}, \mathrm{Si}^{4+}, \mathrm{H}^{+}, \mathrm{OH}^{-}$, and $\mathrm{O}^{-}$and for the illite 
clay mineral with chemical formula $(\mathrm{OH})_{4} \mathrm{~K}_{\mathrm{y}}\left(\mathrm{Si}_{\mathrm{g}-\mathrm{y}} \mathrm{Al}_{\mathrm{y}}\right)\left(\mathrm{Al}_{4} \cdot \mathrm{Mg}_{6}\right.$. $\left.\mathrm{Fe}_{4} \cdot \mathrm{Fe}_{6}\right) \mathrm{O}_{20}$ are $\mathrm{K}^{+}, \mathrm{Al}^{3+}, \mathrm{Si}^{4+}, \mathrm{Mg}^{2+}, \mathrm{Fe}^{2+}, \mathrm{H}^{+}, \mathrm{OH}^{-}$and $\mathrm{O}^{-}[8,12$, $14,17]$. The availability of the exchangeable ions can be seen presented in Figs. 2, 3, and 4. However, research results have shown that by Xray Fluorescence (XRF) and Xray Diffraction (XRD), clayey soil chemical oxide composition is composed also of small proportion of oxides of calcium and oxides of sodium in the case of montmorillonite and this is responsible for its highest degree of expansivity compared to the other three clay mineral components [17]. This means that $\mathrm{Ca}^{2+}$ and $\mathrm{Na}^{+}$are also available as exchangeable ions either during clayey soil hydration or in a case of soil stabilization.

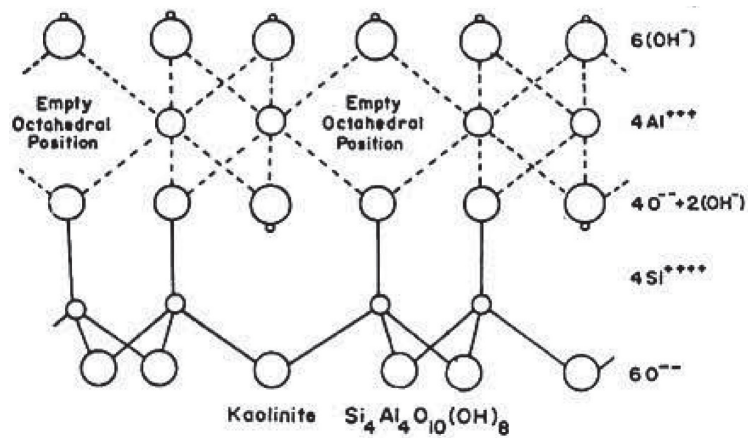

Fig. 2 Structure of kaolinite mineral [8]

2. ábra A kaolinit-ásvány szerkezete [8]

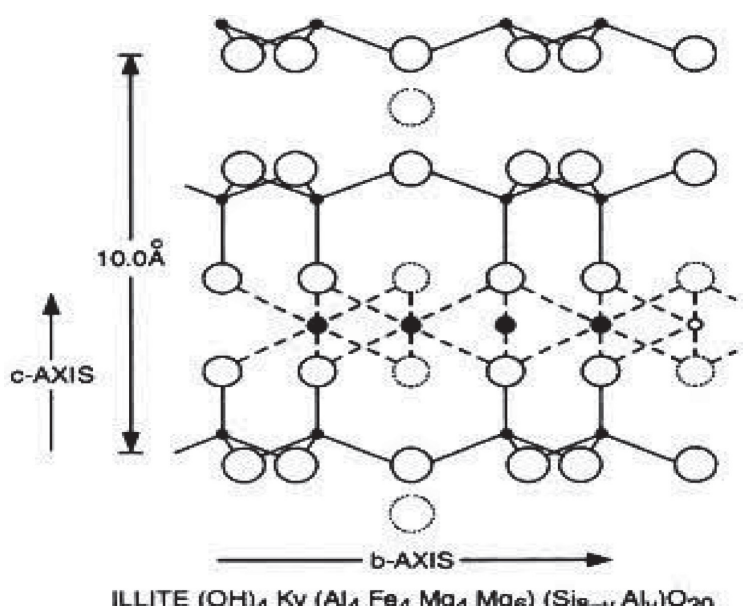

Fig. 3 Structure of illite mineral [8]

3. ábra Az illit ásvány szerkezete [8]

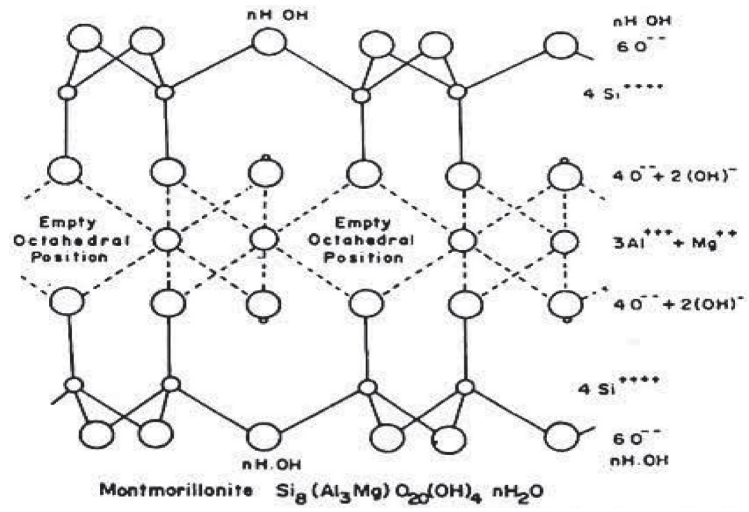

Fig. 4 Structure of montmorillonite mineral [8]

4. ábra A montmorillonit ásvány szerkezete [8]
However, in a clayey soil stabilization procedure, additives are utilized due to the exchangeable ions available, which constitute $\mathrm{Ca}^{2+}, \mathrm{Al}^{3+}, \mathrm{S}^{4+}$, and $\mathrm{Fe}^{2+}$, which are the cations responsible for the binding properties that ordinary Portland cement and other supplementary and alternative binders possess [18-20] and $\mathrm{CO}_{3}^{2-}$, which is the anion responsible for carbonation reaction in stabilization operation $[7,21]$. Clayey soils of highly expansive consistency are not suitable for earthworks due to their high tendency to swell and shrink due to moisture changes [22-25].

\subsection{Hydration, adsorbed moisture and cation exchange reaction in soil stabilization}

Hydration is the inundation or the impregnation of soil and more especially clayey soil in this case, with moisture to trigger ionization in aqueous medium [3,7]. This takes place either through the rise in water table that foundation materials are exposed to moisture ingress or when moisture travels through cracks and percolate into the foundation level $[7,12]$. Clayey soils take in moisture and this causes volume changes known as swelling. As moisture is absorbed, a film of surface is formed in the lattice structures of clay to form what is known as absorbed moisture. The adsorbed moisture in clay is responsible for the dipolation of clay composition ions and the availability of exchangeable ions $[7,23,24]$. The dipole ions from clayey soil are separated into cations and the anions. The anions are concentrated at the surface of the clay particles and attract the cations from the dipole ions from additives during the hydration reaction [7]. The cation exchange reaction takes place with respect to the arrangement of the metallic ions in the electrochemical series. In a montmorillonite dominant clayey soil tetrahedral sheet, $\mathrm{Al}^{3+}$ from chemical additive exchanges $\mathrm{Si}^{4+}$ in clayey soil while either $\mathrm{Mg}^{2+}, \mathrm{K}^{+}, \mathrm{Fe}^{2+}, \mathrm{Li}^{+}$ or $\mathrm{Zn}^{+}$exchanges $\mathrm{Al}^{3+}$ in the octahedral sheet $[7,12]$. During the utilization of additives with sufficient calcium-based components in a soil improvement exercise, $\mathrm{Ca}^{2+}$ also exchanges other weaker cations in the adsorbed complex. These exchange of cations with those that are stronger in the chemical series leads to the formation of clay flocculants responsible for the formation of calcium aluminate hydrate (C-A-H) and calcium silicate hydrate (C-S-H) or even a composite compound known as calcium aluminate silicate hydrate (C-A-S-H) $[1,7$, $10,26,27]$. These compounds are responsible for the gain in strength in clayey soil by the strengthening of the interparticle bonds. When clayey soils swell, with higher degree of swelling potential on the surface of a clayey soil mass, this can be cured through the impregnation and mixing of the swollen soil with such additives rich in exchangeable ions like $\mathrm{Ca}^{2+}, \mathrm{Al}^{3+}$ higher in the electrochemical series that can exchange sodium or magnesium ion to reduce the double diffused layer in swollen soils [6].

\subsection{Swelling potential analytics and stabilization}

The work of H. B. Seed et al. [11] suggested the expression for swelling potential for clayey soils as presented in Equation 1; $w_{S}=0.00216 \times I_{p}^{2.44}$

where $I_{p}=$ plasticity index and $w_{S}=$ swelling potential. 
From the findings of V. N. S. Murthy [12], hydraulically bound foundations built with clayey soils and within the active (unstable) zone experience lattice structure impairments due to moisture intake. The active zone ranges from the clayey soil surface to the depth $D_{\mathrm{n}}$ beyond which the clayey soil belong to the inactive (stable) zone. Volume changes take place within the active zone when foundation materials of clay absorb moisture. During the wet seasons as the water table rises into the active zone, moisture content increases and reaches a maximum at the surface of the compacted mass of clayey soil foundation material [12]. This implies that swelling potential, which is directly proportional to the water intake decreases from maximum at the surface with depth $\left(D_{1}[12]\right.$ to a steady moisture content at the boundary between the active and inactive zones. Consequently, the integral of the swelling potential with respect to the inverse of the depth $(x, D)$ of the foundation matrix is presented in Equation 2.

$\int_{i}^{x} w_{s}=\int_{i}^{x} 0.00216 * I_{P}^{2.44 * \mathrm{dx}^{-1}}$

This operation gives Equation 3 measured along the points of the depths $\left(D_{1}, D_{2}, D_{3} \ldots D_{\mathrm{n}}\right)$ of the foundation soil. And from the findings of V. N. S. Murthy [12], Equation 4 is derived.

$w_{S(x)}=0.00216 * I_{P}^{2.44} *\left(x_{n}{ }^{-1}\right)_{D_{1}}^{D_{n}} ; x^{-1} ; D_{1}, D_{2}, D_{3} \ldots \ldots D_{n}$

Where;

$1 / x_{1}=D_{1}, 1 / x_{2}=D_{2}, 1 / x_{3}=D_{3}, 1 / x_{4}=D_{4}, 1 / x_{5}=D_{5}$

$$
1 / x_{n}=D_{n}
$$

In this case, the point $D_{1}$ is measured from the active-inactive zone boundary as $x_{\max }$ and this point gives the maximum swelling potential at the surface of the foundation material. This shows that $1 / x_{1}>1 / x_{2}>1 / x_{3}>1 / x_{4}>1 / x_{5}>1 / x_{n}$ as presented in Equation 4. Substituting the depth values of D into Equations 5, 6, 7, and 8, the swelling potential at depths $D_{1}, D_{2}, D_{3}, \ldots \ldots D_{n}$ are evaluated.

$w_{s_{1}}=0.00216 * I_{P_{1}}^{2.44} *\left(D_{1}\right)$

$w_{S_{2}}=0.00216 * I_{P_{2}}^{2.44} *\left(D_{2}\right)$

$w_{S_{3}}=0.00216 * I_{P_{3}}^{2.44} *\left(D_{3}\right)$

$w_{s_{n}}=0.00216 * I_{P_{n}}^{2.44} *\left(D_{n}\right)$

It can also be established that the maximum swelling potential is evaluated using Equation 5 with the highest depth value measure from the reactive zone boundary of compacted soil. And finally, the total swelling potential is computed with Equation 9.

$w_{s_{T}}=0.00216 *\left(\sum_{i=1}^{i=n} I_{P_{i}}^{2.44}\right)\left(\sum_{i=D_{1}}^{i=D_{n}} D_{i}\right) ; i ; 1,2,3 \ldots \ldots \ldots \ldots . . \mathrm{n}$

From the above mathematical analysis, it can be observed that the swelling potential at the surface of the compacted clayey soil mass is maximum due to the highest amount of moisture needed for hydration reaction and further formation of the double diffused layer in the clayey soil particles. This further increase the interparticle distances in the clayey soil mass and consequently reduces the van der Waal's force existing between the particles. This also implies that the van der Waal's forces increase with reduced moisture content along the depth of the foundation clayey soil mass. As the mass of compacted clayey soil is inundated with molding moisture or moisture from capillary rise or runoff ingress, the more the exchangeable ions in clayey soils become available for ion exchange reactions and increased double diffused layer and decreased interparticle forces within the clayey soil mass.

\section{Conclusions}

In this work, the ion exchange and swelling potential analytics were reviewed based on previous relevant studies. Swelling in highly expansive soils utilized as construction materials in geoenvironmental engineering and transport geotechnics is an important factor in earthworks. A full understanding of the swell-shrink behavior of highly expansive soils as construction materials is an important phase in the design and construction of foundations. In this review, the exchangeable ions available in a clayey soil utilized in construction were studied. Secondly, the behavior of foundations of clayey soil mass at different depths of the foundation were also discussed. It was established that the use of additive binders rich in exchangeable ions high in the electrochemical series is of utmost important. This leads to the formation of strengthening compounds in a soil stabilization protocol. It was also noted from the swelling potential analytics that in a stabilization procedure, the mixing of chemical additives should be more on the surface of the soil mass and reduced along the depth of the mass. This is to accommodate the highest swelling depth of the foundation soil mass.

\section{Conflict of interest declaration}

The authors declare that they have no known competing financial interests or personal relationships that could have appeared to influence the work reported in this paper.

\section{References}

[1] Onyelowe, K. C., Onyia, M. E., Onyelowe, F. D. A., Bui Van, D., Salahudeen, A. B., Eberemu, A. O., Osinubi, K. J., Amadi, A. A., Onukwugha, E., Odumade, A. O., Chigbo, I. C., Saing, Z., Ikpa, C., Amhadi, T., Ugorji, B., Maduabuchi, M., Ibe, K. (2020). Critical state desiccation induced shrinkage of biomass treated compacted soil as pavement foundation Epitöanyag Journal of Silicate Based and Composite Materials, vol. 72 (2), pp. 40-47.

[2] Soon, N. W. et al. (2013). Improvement in engineering properties of soils through microbial-induced calcite precipitation. KSCE Journal of Civil Engineering, vol. 17, pp. 718-728. https://doi.org/10.1007/s12205-013-0149-8

[3] Hervé Peron, Lyesse Laloui, Tomasz Hueckel \& Liang Bo Hu (2009). Desiccation cracking of soils, European Journal of Environmental and Civil Engineering, 13:7-8, 869-888, https://doi.org/10.1080/19648189.2009.9693159

[4] ASTM D4318-17e1 (2017). Standard Test Methods for Liquid Limit, Plastic Limit, and Plasticity Index of Soils, ASTM International, West Conshohocken, PA. https://doi.org/10.1520/D4318-17E01

[5] Shigeki, I. and Toshio, S. (1965). Chemical Reactions Among Clay Minerals' Calcium Carbonate, And Ammonium Chloride, The American Mineralogist, VOL. 50, July_August'.

[6] McBride, M. B. (1997). A critique of diffused double layer models applied to colloid and surface chemistry. Clays and Clay Minerals, vol. 45 (4), pp. 598-608.

[7] Bui Van, D. and Onyelowe, K.C., 2018. Adsorbed complex and laboratory geotechnics of Quarry Dust (QD) stabilized lateritic soils. Environmental Technology and Innovation, Vol. 10, pp. 355-368. https://doi.org/10.1016/j.eti.2018.04.005.

[8] R. E. Grim (1953). Clay mineralogy, chaps. 4, 7, 8, 9, 10, 13. McGraw-Hill Book Company, Inc., London.

[9] Rose, D. A. et al. (1997). A model based on diffuse double layer theory to predict soil salinity. Joint Intl. Conf. on Agric. Engg. \& Tech. Exhibition, '97, Dhaka 
[10] Onyelowe, K. C., Bui Van, D., Dao-Phuc, L., et al. (2020). Evaluation of index and compaction properties of lateritic soils treated with quarry dust based geopolymer cement for subgrade purpose. Epitőanyag- Journal of Silicate Based and Composite Materials, Vol. 72, No. 1, pp. 12-15. https://doi.org/10.14382/epitoanyag-jsbcm.2020.2

[11] Seed, H. B. et al. (1962). Prediction of swelling potential for compacted clays. Journal of Soil Mechanics and Foundation Division, vol. 88(3), pp. 53-87.

[12] V. N. S. Murthy (2007). Advanced geotechnical engineering; geotechnical engineering series. CBS Publishers and Distributors, New Delhi.

[13] Ambrus, Maria (2019). Mechanikai aktivalas hatasa deponalt pernye alapu geopolimerek nyomoszilardsagara Epitőanyag- Journal of Silicate Based and Composite Materials, Vol. 71, No. 5, pp. 148-152. https://doi.org/10.14382/epitoanyag-jsbcm.2019.26

[14] Das, B. M. and Sobhan, K. (2012). Principles of geotechnical engineering, $8^{\text {th }}$ edition. Cengage Learning, Stamford, USA.

[15] Chen, F. H. (1988). Foundations on Expansive Soils, $2^{\text {nd }}$ Edition, Elsevier Services Publications, New York.

[16] D. L. Rimmeri and D. J. Greenland (1976). Effects of Calcium Carbonate on The Swelling Behavior of a Soil Clay, Journal of Soil Science, 27. 129-39.

[17] Onyelowe, K. C., Aririguzo, J. C. \& Ezugwu, C. N. (2019). Sustainable Soils Re-Engineering. Partridge Publishing, Singapore. ISBN 9781543750997

[18] American Standard for Testing and Materials (ASTM) C618 (1978). Specification for Pozzolanas. ASTM International, Philadelphia, USA.

[19] BS 8615-1 (2019). Specification for pozzolanic materials for use with Portland cement. Natural pozzolana and natural calcined pozzolana. British Standard International, London.

[20]ASTM D4829-19 (2019). Standard Test Method for Expansion Index of Soils, ASTM International, West Conshohocken, PA. https://doi.org/10.1520/D4829-19

[21] Haas, S. and Ritter, H. F. (2019). Soil improvement with quicklime-longtime behavior and carbonation. Road Materials and Pavement Design, vol. 20(8), pp. 1941-1951. https://doi.org/10.1080/14680628.2018.1474793

[22] Lewis, D. R. (1988). Ion exchange reactions of clays. Exploration and Prodviction Research Division, Shell Development Co., Houston, Texas. Publication No. 26, Pp. 54-69
[23] Tisdale, S. L. et al. (1975). Soil Fertility and Fertilizers-Chapter 4-Ion Exchange in Soils. $4^{\text {th }}$ Edition, Macmillan Publishing Company, New York.

[24] G. P. Robertson et al. (1999). Standard Soil Methods for Long-Term Ecological Research, Chapter 6: Exchangeable Ion, $\mathrm{pH}$ and Cation Exchange Capacity. Oxford University Press, New York.

[25] A. Goraczko and A. Olchawa (2017). The Amounts of Water Adsorbed to the Surface of Clay Minerals at the Plastic Limit. Archives of HydroEngineering and Environmental Mechanics, vol. 64 (3-4), pp. 155-162. https://doi.org/10.1515/heem-2017-0010

[26] K. C. Onyelowe, A. B. Salahudeen, A. O. Eberemu, et al. (2020b). Utilization of Solid Waste Derivative Materials in Soft Soils Re-engineering. In book: Recent Thoughts in Geoenvironmental Engineering, Proceedings of the 3rd GeoMEast International Congress and Exhibition, Egypt 2019 on Sustainable Civil Infrastructures - The Official International Congress of the Soil-Structure Interaction Group in Egypt (SSIGE), pp. 49-57. https://doi.org/10.1007/978-3-030-34199-2_3

[27] J. F. Rivera, A. Orobio, R. Mejia de Gutierrez et al. (2020). Clayey soi stabilization using alkali-activated cementitious materials. Materiales de Construccion, vol. 70 (337), pp. 1-12. https://doi.org/10.3989/mc.2020.07519

[28] Amadi, A. A. and Okeiyi, A. (2017). Use of quick and hydrated lime in stabilization of lateritic soil: comparative analysis of laboratory data. International Journal of Geo Engineering, vol. 8(3). https://doi.org/10.1186/s40703-017-0041-3

Ref.:

Onyelowe, Kennedy C. - Onyia, Michael E. - Bui Van, Duc - Firoozi, Ali A. - Amhadi, Talalh: Analytics of swelling potential on highly expansive (plastic) clayey soils behavior for sustainable admixture stabilization

Építőanyag - Journal of Silicate Based and Composite Materials, Vol. 73, No. 3 (2021), 86-90. p. https://doi.org/10.14382/epitoanyag-jsbcm.2021.13

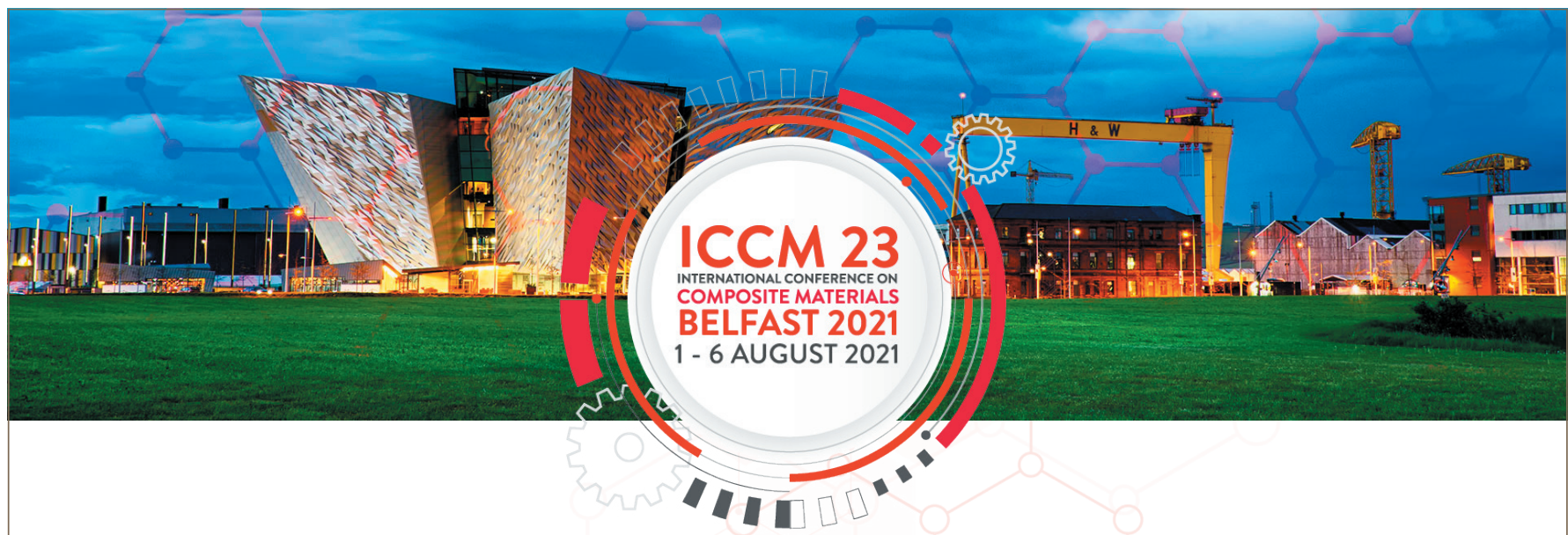

The 23rd International Conference on Composites Materials (ICCM 23) will be held in Belfast, Northern Ireland, from the 1st to 6th of August 2021. ICCM is the premier international conference in the field of composite materials and was first held in 1975 in the cities of Geneva and Boston. Since that time the conference has been held biennially in North American, European, Asian, Oceanic, and African cities.

ICCM 23 will attract the leading researchers and practitioners, to report and exchange ideas on the latest developments in the advancement and exploitation of a wide range of composites materials and structures. The general themes of material development, testing, modelling, manufacturing and design will encompass a breadth of topics which will provide a comprehensive global snap-shot of the state-of-the-art. Plenary and keynote lectures from pre-eminent leaders in the field are planned, along with oral and poster presentations from an expected large delegation coming together in Belfast from all corners of the world. A number of site visits and an entertaining social programme are also planned.

\section{iccm23.org}

